\title{
Is Scotland a Westminster-style Majoritarian Democracy or a Scandinavian-style Consensus Democracy? A comparison of Scotland, the UK and Sweden.
}

\begin{abstract}
The idea of 'new politics' in Scotland, in the 1990s, was based on a rejection of the 'majoritarian' politics of 'old Westminster' in favour of a 'consensus democracy' associated with Scandinavian countries. Yet, the nascent literature suggests that Scottish and UK policymaking practices are similar. UK policymaking does not live up to its majoritarian reputation and Scotland was designed with key 'old Westminster' features. We extend the comparison to Sweden, as one of several, distinctive, Nordic reference points in Scotland. We examine critically its consensual image and identify the ways in which Scotland has similar features. The study helps clarify the practical meaning of majoritarian and consensus and encourages scholars to focus on actual behaviour rather than policymaking reputations. It also informs current debates on Scotland's future, using long term evidence to inform recent attempts to revive this focus on the Nordic ideal.
\end{abstract}

\section{Keywords}

British politics - consensus - majoritarian - Scottish politics - Swedish politics

\section{Introduction: Beyond Majoritarian-Consensus Caricatures}

Misleading caricatures of political systems, based on their formal institutions or reputations, are difficult to shake off, both academically and politically. The UK has long been described as a 'majoritarian' system in contrast to the Scandinavian (Sweden, Norway, Denmark) 'consensus democracies', even though they have long shared common features and practices (Richardson, 1982; Ruin, 1982). The UK 'never fitted the majoritarian caricature' (Author, 2013). Scandinavian consensualism is often a cliché; a romanticised past existence with limited empirical support, and with marked differences in country level experiences (Hilson, 2008: 54; Bergman and Strøm, 2011).

Yet, these romantic ideas about consensus democracies, and negative images of majoritarian democracies, have informed two major referendum debates on Scottish constitutional change: devolution in 1997 and independence in 2014. Devolution was sold by many groups as an opportunity to reject 'old Westminster', broadly in favour of the consensual practices of the Scandinavian democracies (Arter, 2004). To date, the Scottish experience suggests that these aspirations were not reinforced by reality. Most importantly, Scottish reformers shared power with UK Government bodies with different ideas, and the Scottish system was designed with some elements drawn directly from Westminster and with less direct reference to Scandinavian systems (Author, 2013).

Such misleading reputations display remarkable powers of endurance, academically and politically. They are often killed off in the specialist country-specific literature, and then resurrected in large comparative quantitative studies or textbooks (Author, 2013). Further, independence is now being sold again, by some groups, as a means to get further away from 
Westminster politics, or its style of policymaking and its policy trajectory, and closer to a 'Nordic' ideal'. The 'Nordic Model' has become a rather stylised 'ideal type', based on a broad focus on alleged common features - including corporatism, universal welfarism and a 'political culture of consensus' - and there is not a widespread recognition that different countries compare with the ideal-type in different ways (Harvey, 2013; Keating and Harvey, 2014: 61).

In this context, we need analysis which goes beyond such academic and political stereotypes, to chart the real, comparable features of the political systems which represent Scotland's key reference points. This requires us to focus in-depth on individual country experiences, and to recognise that the results represent only one piece of the overall Nordic experience (particularly if 'Nordic' extends the comparison to five countries, including Finland and Iceland). To that end, we focus on post-war Sweden as one of several influential comparators in Scotland (see Kvist and Greve, 2011 and Christiansen and Togeby, 2006 on Denmark, and Østerud and Selle, 2006 on Norway).

We do so with two points in mind. First, we should consider a wider range of explanations, for political system differences, than summed up in the majoritarian/ consensus distinction which focuses primarily on factors such as electoral systems and their effect on political cultures. Second, we should consider the extent to which UK, Scottish and Swedish systems share features that are common to many political systems - such as an imbalance of resources between government and parliament, and a tendency for policy to be made outside of the parliamentary arena. The public policy literature suggests that political systems are influenced by 'universal' processes, such as the 'bounded rationality' (Simon, 1976) of policymakers: they are unable to pay attention to most of the issues for which they are responsible. So, parliaments devolve policy making responsibility to governments. In turn, government ministers devolve most responsibility to civil servants, who make policy in partnership with 'pressure participants' such as interest groups - a process summed by concepts such as 'policy community', 'network' or 'subsystem' (Jordan et al, 2004; Baumgartner and Jones, 2009; Richardson and Jordan, 1979; Author, 2012, 179). While this process may be managed differently in different systems, their practices are influenced by factors other than differences in constitutional design - such as the nature of each policy issue, the economic environment, and the size of the political system which, for example, influences the ability of policymakers to form personal relationships with pressure participants (Author, 2012).

In this context, we have two aims. First, we provide an overview of the relevant literature, comparing texts that describe majoritarian/ consensus as a key contrast between political systems, and texts that challenge the value of the distinction or show that very differentlooking systems often engage in policymaking in very similar ways. We compare the longestablished images of majoritarian versus consensus practices presented by Lijphart (1984; 1999) and Elder et al (1982) with the idea of a common 'European policy style' presented by Richardson (1982, drawing partly on Heisler and Kvavik, 1974). This allows us to clarify the majoritarian/ consensus distinction, as a way to describe either formal differences or 
actual behaviour and outcomes, to help compare the UK with Sweden in a more nuanced way.

Second, we consider our ability to characterise Scotland's political system with reference to these competing images. Going beyond too-simple reputations requires us to identify more complicated comparisons. The 'majoritarian' UK and 'consensus' Sweden have long shared many policymaking practices and, in some respects, their practices have converged since the early post-war period. We cannot categorise Scottish practices in a simple UK versus Sweden way. Further, the Scottish system was modelled largely on Westminster, with only some features, such as its electoral system, associated with consensus democracies, and very little evidence of political design based directly on Swedish (or Scandinavian) practices. We would expect to find, in Scotland, a mixture of majoritarian and consensus elements, but those elements will not necessarily resemble Sweden's directly. Finally, our impressions may vary according to our focus. Consequently, we compare two key areas: executive-legislature relations, to examine consensus seeking between governing and opposition parties in parliament; and group-government relations, to examine the extent to which governments seek consensus with pressure participants.

\section{Majoritarian and Consensus Democracies: What Do They Mean?}

Lijphart (1984; 1999) makes a highly influential, though often-criticised, distinction between majoritarian and consensus democracies. It is based on quantitative analysis of the formal institutional structure of political systems, divided into two categories. In the 'executivesparties dimension', plurality systems concentrate power in the executive and foster adversarial two-party politics; proportional representation spreads power and fosters cooperative multi-party systems. These differences extend to the group-government arena, with consensus democracies associated with closely-cooperating corporatist structures 'aimed at compromise and concertation' and majoritarian systems linked to fluid group-government relationships and 'free-for-all competition among groups' (1999: 5). Majoritarianism is reinforced when there is executive dominance of the legislature. In the 'federal-unitary dimension', majoritarianism is reinforced by: unitary and centralised government; unicameralism (or a weak upper chamber); no scope for judicial review of the constitutionality of government policy; an absence of a strong written constitution; and, a government controlled central bank.

Lijphart (1999: 7) treated the UK as an archetypal majoritarian system. Flinders' (2010) updated study, published before the coalition government of 2010, still describes much of the UK as majoritarian even though the UK Government granted independence to the Bank of England and devolved powers to Scotland, Wales and Northern Ireland. The Scottish comparison has to be limited because some elements on the 'federal-unitary dimension' are not applicable to a devolved political system, which does not control its own constitution or central bank. However, Flinders (2010: 176) still identifies 'bi-constitutionality' following the promotion of consensus-democracy-like features in the devolved territories. For example, the Scottish Parliament's proportional electoral system provides a new context conducive to 
power sharing between parties, government and Parliament, while the UK maintained majoritarian institutions and practices in central government (Flinders, 2010: 177).

Lijphart (1999: 248) only provides heavily qualified support for the argument by Elder et al that there is a 'distinctly Scandinavian culture of consensus'. Elder et al (1982: 10-11) use different, more qualitative and historical, criteria and methods to identify Scandinavian consensualism: low public opposition to the political system and its rule of law (measured with reference to factors such as minimal political violence, generally low public support for anti-system parties, and high voting rates); low conflict within the political system (coalition building in parliament); and, high levels of coalition building during the production of public policy (the relationships between government and groups such as unions and business groups).

Further, Lijphart (1999) did not describe Sweden as an archetypal consensus system. It scores well on the 'executives-parties' dimension but less well on 'federal-unitary' because it has been unicameral since 1971 and its central bank was made independent from government and parliament only in 1999. Its constitutional review of legislation is also sometimes criticised as weak - although it was strengthened in a constitutional reform package passed in 2010.

In this context, the majoritarian-UK and consensus-Sweden comparison, applied to Scotland, is not straightforward, since it may depend on different criteria by different studies. Yet, drawing on this approach, and using the most relevant and meaningful comparisons, relating to the 'executives-parties' dimension, we can identify two forms of behaviour associated with Sweden:

1. Consensus seeking between governing and opposition parties in parliament.

2. Consensual cooperation between the government and pressure participants.

Further, Lijphart's argument is that the culture that develops in one arena (parliament) influences the culture in another (group-government relations). On that basis, and using this literature, we would expect Sweden's set-up to contrast with the alleged tendency, in majoritarian democracies such as the UK, to concentrate power within governments at the expense of opposition parties and pressure participants.

\section{An Alternative View: The Common European Policy Style}

The 'policy communities' literature questions the influence of parliaments and, therefore, the practical effect of adversarial versus consensual parliamentary arenas (Richardson and Jordan, 1979; Author, 2013: 236; compare with Arter, 1984: 37-41). Instead, we should make comparisons between the relationships that develop between governments and pressure participants. Most policy decisions are effectively beyond the reach of parliaments and senior policymakers. The size of government is addressed by breaking policy down into more manageable issues involving a smaller number of interested and knowledgeable participants. Most public policy is conducted through small and specialist 'policy communities'. Policymaking arrangements develop because there is a logic to devolving decisions and 
consulting with certain groups. Ministers rely heavily on their officials for information and advice. For specialist issues, those officials rely on specialist organisations. Organisations trade information, and other resources, for access to government (Richardson and Jordan, 1979; Jordan and Maloney, 1997; Author, 2013; Author, 2012). This is the dominant interpretation of contemporary British policymaking, even if it is expressed in different ways, and if studies of 'governance' are now more prevalent than 'policy networks'. The British literature focuses on governmental subsystems at the heart of policymaking, with Parliament at the periphery (Kerr and Kettell, 2006; Marsh, 2008; 2012; Rhodes, 2011).

The importance of Richardson's (1982) edited volume Policy Styles in Western Europe is that the same logic applies to many democracies (Jordan and Richardson, 1983: 264). It encourages us to focus primarily on the policy community, not parliamentary, arena to best compare policy processes. On that basis, Richardson (1982) found that the 'British Policy Style' had much in common with policy styles in countries such as Sweden. Their common 'European policy style' could be described as (a) an approach to problem-solving which was largely incremental rather than 'anticipatory' and radical (government policy was built on past decisions, not a rejection of them) and (b) a consultative rather than impositional relationship between the government and pressure participants (Richardson et al, 1982: 1213; Author, 2013).

The argument that the 'British policy style' is consultative and non-radical despite the UK's majoritarian image is recognised by Elder et al (1982: 28) - 'the British system is much more consultative than the superficialities of adversary politics might suggest' - and has since been reinforced in numerous contemporary studies (Author, 2013). Consequently, a description of countries as 'consensus democracies' does not differentiate them clearly from the UK.

\section{Contingent Swedish Consensualism?}

This lack of a Sweden-UK contrast is reinforced when we find that Sweden's image of consensus relates to a particular, mostly early postwar, era with specific policy conditions: a historic period of economic growth, social cohesion, and constitutional continuity; and, long periods of, often minority, single party rule, in which the Social Democratic Party (SAP) sought wider legitimacy through parliamentary and group consultation. During this time, norms developed to guide Swedish policymakers: 'seek agreement among participants and avoid conflict; ... try to build large majorities for policies rather than force their standpoint on minorities; and compromise rather than cling rigidly to their own preferences' (Ruin, 1982: 141). It was possible to identify a 'standard operating procedure' in which the government set up a commission of inquiry to make policy recommendations which form part of a draft government bill, considered and approved by a parliamentary committee, before being 'worked out within the administration' - a process that could take six to eight years between the first referral and the implementation (1982: 142).

The continuous inclusion of parliament - or its political parties - in government deliberations, before and after the legislation is put to parliament, and the time taken to 'find solutions acceptable to all concerned', marked Sweden out from countries such as the UK (1982: 154; 
Elder et al, 1982: 159-91). This 'normal style' was most evident in 'foreign, defence and constitutional policy' (but less evident in 'labour market, industrial and tax policies') while the development of its welfare state and education system are high profile examples of innovative, 'anticipatory' policymaking to ensure major policy change (Ruin, 1982: 142).

However, socio-economic and constitutional changes have undermined these standard operating procedures. Sweden's policymaking image - 'deliberative, rationalistic, open and consensual' (Anton, 1969) - was 'coupled to a growth economy' and a 'fairly homogeneous' population (Ruin, 1982: 143-5). Post-war corporatism flourished following the production of unusual Swedish circumstances - including its 'late and rapid economic development' and its neutral role during world wars - and when its economic policy was in everyone's 'individual and collective self-interest' (Steinmo, 2010: 33). Business and labour could cooperate when egalitarianism operated in tandem with economic growth ('everyone benefits and everyone pays' - 2010: 34). Diminished economic performance and rising unemployment, linked to the rise of foreign competition, inflation and the oil crisis in the 1970s, put pressure on groupgovernment relations. 'Peak corporatism', in which macroeconomic policy was managed by leaders of government, business and labour, became less relevant to a 'globalised' and 'Europeanised' economy less subject to central control (Arter, 2008: 164; Bergman and Bolin, 2010: 252).

Further, immigration from the 1960s exacerbated social tensions and reduced the 'possibility of reaching agreement' (Ruin, 1982: 147; Einhorn and Logue, 2003: 117). Sweden experienced significant labour immigration in the 1960s and 1970s and asylum immigration from the 1980s. Initially, immigration-critical parties found it difficult to progress. When an anti-establishment party seeking to politicise immigration entered parliament in 1991, it selfdestructed after one term (Widfeldt, 2000). The traditional left-right divide remained the most important conflict dimension (Rydgren, 2002; 2006). More recently, the challenge from socio-cultural issues has gained momentum. Immigration has divided public opinion significantly since the early 1990s (Sandberg \& Demker 2013), becoming a key election issue in 2002. The far-right Sweden Democrats entered Parliament in 2010 and immigration issues remain politicised. In addition, protests from environmental, feminist and student groups, starting in the 1960s, further reinforce the broad idea of a break away from consensualism (Arter, 2008: 48).

These changes took place in tandem with constitutional change; the establishment of a unicameral system and new processes of national and local elections in 1970 (Ruin, 1982: 149-50). One consequence was the eventual loss of a working majority in parliament for the SAP, which had been in government for four decades and was associated with the promotion of strong group-government relations, industrial harmony, and a broader hegemonic project to maintain the high tax and large welfare state model (Elder et al, 1982: 27; 188; Heclo and Madsen, 1987: 9). Elections from the mid-1970s may have marked an 'ideological backlash against the Social Democratic welfare state' (Hilson, 2008: 44-7).

In this context, the pursuit of consensualism may be perceived as the stifling of debate and dissent (Heclo and Madsen, 1987; Ruin, 1982: 155; Hinnfors, 1997: 165). It became more 
difficult as the policy arena became overcrowded following a massive rise in groups seeking influence. 'ii 'Consensus' was increasingly achieved by agreeing vague policy decisions and producing 'framework' legislation which shifted conflict to the implementation stage, or regional/ local government (1982: 156-8). Or, more pressing policy issues often produced "'fire brigade' actions" by the government, outside the normal policy style (Ruin, 1982: 162).

Overall, Swedish politics displays a long culture of consensualism as a standard operating procedure, but with evidence of change: a post-war period characterised by governments with secure parliamentary positions seeking consensus with groups was replaced, from the mid1970s, by governments with weaker parliamentary positions struggling to find the same kinds of policy agreements with groups. Its image as a consensus democracy seems contingent on political and socioeconomic conditions that came under challenge from the 1970s.

\section{Can Scotland be a Majoritarian and Consensus Democracy?}

This section considers the applicability of these modified images of majority and consensus politics to Scotland, focusing on two key dimensions.

\section{Parties and Parliament in Scotland: closer to the UK or Sweden?}

We may associate with Sweden a committee-centric parliament in which government and opposition parties make meaningful attempts to produce legislative solutions. The 'real political job - including the parties' fundamental strategic considerations - has to be done in the committees' (Hinnfors, 1997: 162). Sweden has a "“working parliament' served by a system of multi-functional, specialist committees" (Arter, 2004: x11), and, 'Compared to Anglo-Saxon systems, activity in the Parliament is focused on political decision-making rather than on criticizing and controlling government' (Hinnfors, 1997: 161).

However, we also expect political systems to face common pressures. Sweden may have a more important parliamentary process, but in the context of a government-parliament relationship in which the former is responsible for day-to-day policymaking and the latter has limited resources to scrutinise and influence government activity. As in the UK and Scotland, the main role of the Riksdag is to process government legislation (Arter, 2004: 158-9). Swedish distinctiveness relates more to the relationship between governing and opposition parties than government and parliament.

The Scottish experience adds to our comparative knowledge; it shows the limits to any attempt to change this government-parliament relationship, by encouraging, in a vague way, a new culture of 'power sharing' without a significant shift of resources (Author, 2013). Proponents of Scottish devolution - such as the Scottish Constitutional Convention (SCC) (1989; 1995) - a collection of political party and 'civil society' groups (Author, 2013: 11) used 'old Westminster' as a 'negative template' for 'new Scottish politics' and took some inspiration from countries such as Sweden (although Arter, 2004: 20 suggests that policy learning was 'rushed' and not 'evidence-based'). It advocated a consensual style of politics, over the adversarial style in Westminster, and 'power sharing' with the Scottish Parliament rather than executive dominance (Author, 2008: 11-2). The Scottish system partly reflects 
that reform agenda, producing a consensus democracy in Lijphart's (1999) 'executiveparties' terms (Flinders, 2010: 275). It has a proportional electoral system with a strong likelihood of bargaining between parties; it uses a mixed-member proportional system, with 73 members elected via first-past-the-post constituencies and 56 from 8 regions using a list system.

These themes were taken up by the 'Consultative Steering Group' (CSG) established by the UK Government to report on the draft rules for the Scottish Parliament (Scottish Office, 1998). It invested in Scottish committees an unusual range of powers compared to the legislatures of most West European countries. The Scottish Parliament has permanent and specialized committees with combined standing and select committee functions, a proportional (by party) number of convenors (chairs), committee deliberation both before the initial and final plenary stages of legislation, the ability to initiate and redraft bills, invite witnesses, demand government documents, and monitor pre-legislative consultation. These are indicators of unusually high committee strength according to Mattson and Strøm's (2004: 100-1) criteria and, 'Outside Austria, only the Swedish and Icelandic committees have comparable powers' (Arter, 2004: xi).

Yet, the Scottish Parliament also shares with Westminster an imbalance of policymaking power towards the executive. It has many 'old Westminster' characteristics including the same constitutional format (the executive resides in the legislature), division of resources (the majority of spending is controlled by the Scottish Government) and expectation that the government will govern (Author, 2011a: 13; Author, 2013). This is no accident - 'new politics' reformers captured the imagination, but the UK Government, concerned more with traditional forms of government accountability through parliament, designed the Scottish Parliament (Author, 2013).

Consequently, the Scottish Parliament is subject to practical constraints relating to the limited resources it has in comparison with the Scottish Government - including committees with 7-9 members - 'the smallest of any national parliament in Western Europe' (Arter, 2004: 31) and a few dozen parliamentary staff working directly on scrutiny and research, overseeing a public sector with half a million employees spending a budget of around $£ 30$ billion (Author, 2013: 92). In comparison, each Swedish committee has a minimum of 15 members and 5-8 staff working directly for them (approximately 100 in total) (Arter, 2004: 167) and the comparable employees and budget are 1.25 million and £170bn. Scottish Parliament committees also struggle to conduct parliamentary business in a restricted time, which has only recently expanded to Tuesday-Thursday mornings. These problems prompted its Procedures Committee (2003, paragraph 1016) to worry about the Parliament becoming a 'conveyor belt for passing legislation' to the detriment of scrutiny and influence.

The more constraining factor, particularly during majority government, is the role of highly 'whipped' political parties. In the parliamentary terms of 1999-2003 and 2003-7, Scottish Labour, the largest party, formed a majority coalition government with the Scottish Liberal Democrats, securing 73 (57\%) and then 67 (52\%) of 129 seats. The governing coalition had enough MSPs to control the parliamentary business bureau and ensure a voting majority on 
all committees, with voting cohesion high among both parties (Author, 2011a: 39). The parties also appoint their own convenors and decide which MSPs sit on which committees.

The coalition produced the closest thing possible in Scotland to majoritarian government in a government-versus-opposition atmosphere (Arter, 2004: 83; Author, 2006; Author, 2011a: 29-30; Author, 2008: 85; Mitchell, 2008: 77). It produced 'partnership agreements' that tied both parties to a detailed programme of legislation without seeking agreement from opposition parties. It dominated the legislative process, and committees became part of a 'legislative sausage machine' (Arter, 2002: 105). While there is some evidence of parliamentary influence during the scrutiny of government legislation, the Scottish Government produced and amended the majority of bills (Author, 2005; Author, 2006; McGarvey and Author, 2008: 106), reinforcing Olson's rule that executives initiate $90 \%$ of legislation and get $90 \%$ of what they want (Arter, 2006: 250).

In 2007, the SNP (47 seats) replaced Scottish Labour (46) as the largest party, and it formed a minority government from 2007-11 (it formed a majority government in 2011). Its minority status had some impact, but also demonstrated the imbalance of power between Government and Parliament in four ways. First, the Scottish Parliament reinforced the expectation that the government retain primary responsibility to legislate. Committees proved unable or unwilling to produce agenda setting inquiries or significant legislation. Second, the Scottish Government pursued many of its policy aims without primary legislation or parliamentary permission, using its budget and existing laws. Third, small committee size, MSP turnover, and some disengagement by some parties, undermined the abilities of committees to scrutinize government policy. Further, the decision by the Scottish Government to devolve more responsibilities to local authorities has undermined the Scottish Parliament's scrutiny function. Fourth, the SNP Government lost more votes than its predecessors, and did not introduce two key bills on an independence referendum and reform of local taxes, but its legislative programme remained intact and few bills were amended against the SNP's wishes (Author, 2011a; 49-54). The relationship between the SNP and the former Scottish Government parties (Labour and Liberal Democrats) remained tense (Author, 2011: 49).

The Scottish experience highlights many processes that we associate with Westminster - but does this mean that it contrasts with the Riksdag? Scotland shares more institutional features with Sweden, including an electoral system producing more elected parties. It also has a unicameral parliament designed to 'front load' its legislative process - the principles and details of bills are considered initially by committees, to address issues early, in a system without a second chamber to address issues after a bill is passed by the first. The Swedish system also contains parties with a strong whip; 'individualistic voting' is as rare in Sweden as it is in Scotland (Arter, 2004: 25). Indeed, cohesion may be a precondition for its 'bargaining government' which comes primarily from negotiations between parties, not individuals in committees (2004: 162).

Nevertheless, there are important differences. First, there have been different attitudes to the formation of governments. Arter (2004: xii) suggests that the norm in Sweden, Norway and Denmark was for minority governments to be 'backed by legislative coalitions giving them a 
de facto majority'. This differs from the first eight years in Scotland where Scottish Labour and the Scottish Liberal Democrats formed a majority coalition government with no need to find opposition party support in parliament (majoritarian coalitions are more of a feature in Finland and Iceland - 2004: 257). This betrays a cultural attachment in Scotland to stable government - linked, in the eyes of the main parties, to the ability to guarantee control of the parliamentary arithmetic (Author, 2011b; Arter, 2004: 258).

The minimum-winning-coalition mentality in Scotland perhaps reflects its UK majoritarian history. An initial reliance on majority government rather than cross-party cooperation also reflected, to a large extent, the tensions between the two major parties in Scotland, Scottish Labour and the Scottish National Party (SNP). While they are often difficult to separate on the left-right scale, ${ }^{\text {iii }}$ they are very strongly divided on the 'centre-periphery' cleavage (Lipset and Rokkan, 1967), with Scottish Labour viewing devolution as a 'settlement' and the SNP favouring Scottish independence. Scottish Labour favoured majority coalition over minority rule, since it feared a loss of control, and threat of 'ambush', if it had to rely on regular cooperation with the SNP (Arter, 2004: 83; Author, 2011: 41-2).

This practice contrasts with a historic tendency for the Swedish government to consult routinely with opposition parties in arenas such as government commissions which perform pre-legislative scrutiny. Such measures were not introduced in Scotland and, while their use was debated post-devolution, they were rejected to maintain clear 'lines of accountability' (Arter, 2004: 260).

There are some signs of convergence. For example, a minority Scottish government required the support of at least one other party to secure its legislative programme. However, committees remained peripheral to the legislative process. Scottish Labour seemed most reluctant to engage in detailed policy work, before and during the passage of legislation, and committees rarely agreed on the pursuit of major inquiries (Author, 2011a: 51). There is no equivalent to the Swedish process of regular bargaining between government and opposition parties. There was some need for the minority government to seek the support of other parties, and it worked well with the Conservative party, particularly to secure its annual budget bill, but not in the spirit we associate with Sweden's 'bargaining democracy' (Arter, 2004: 16).

The comparison is complicated by different arrangements in which Swedish party bargaining takes place, often informally, outside parliament. Scottish Parliament committees take on the bulk of the detailed legislative scrutiny - they invite witnesses, co-opt external experts to aid scrutiny and engage with ministers in line-by-line scrutiny of draft bills. Further, the hope was that committees would operate in a 'businesslike' manner, with MSPs balancing their party affiliations with the need to produce cross-party agreement. In Sweden, 'inter-party bargaining across the government-opposition divide' takes place elsewhere - in government commissions and in informal regular discussions between parties - before bills reach Riksdag committees (Arter, 2004: 137; 160-8; 256). Consequently, 'Parliament as an institution affirms or denies policies that have been initiated elsewhere' (Heclo and Madsen, 1987: 11). 
The architects of a Scottish Parliament could not easily design a system built so much on a culture of bargaining between parties. This difference may be accentuated by the larger scope for Swedish policy responsibilities. Most Scottish Governments can rely on widespread, often implicit, support for a social policy agenda on which most parties broadly agree. In a devolved, not independent, Scotland there is no equivalent need for parties to bargain to secure broad agreement in 'high politics' (Arter, 2004: 256), which might underpin and set the tone for subsequent deliberations, since it is not responsible for economic, foreign and defence policy.

Yet, some similarities can be identified in relation to periods of Swedish majority-building, and often a reduced incentive to consult as widely across the parties. Sweden had majority government, led by the Moderate party, as recently as 2006-10. Further, the goal for the centre-right and centre-left blocs, to get back to majority government, is not necessarily based on an unwillingness to seek majorities. In other words, minority government need not be the norm. Rather, it is often hindered by their unwillingness to cooperate with parties they find unacceptable, such as the far-right Sweden Democrats and, further back in history, communist parties.

\section{Government, Groups and Consultation: Trends in Sweden}

Sweden's longstanding reputation suggests that it uses a formal system of group-government relations in which governments set up commissions of inquiry to investigate policy change. Heclo and Madsen (1987: 9; 12-3) describe a 'Swedish penchant for structured consultation' or the organisation of pressure 'in stable, predictable and orderly ways', played out in a 'complex set of clearances, joint working groups, and above all commissions to involve recognized spokespersons in joint decision making forums'. Commissions of inquiry revolve around civil servants consulting with 'individuals with specialized political, administrative, interest group and professional roles' to solve policy problems (1987: 12). Further, the 'official legal responsibility' for commissions rests in the cabinet, allowing 'most deliberations' to be coordinated by civil servants and 'carried on in semiprivate conditions' (1987: 13).

This is not a major departure from the 'policy community' image identified in the UK, and Richardson and Jordan (1979: 115-7) describe similar processes of consultation and commission-forming in the postwar period (compare with Heclo and Madsen, 1987: 21) There are two potential exceptions. First, there is a greater initial sense of formalised openness in Sweden, with the setup of an unusually large number of commissions, whose reports inform parliamentary output, subject to public consultation. Second, there is a semiroutine role for political parties, whose representatives sit alongside interest group representatives on some commissions (1987: 13). This is not a feature identified in the UK or Scottish literature; it is more likely to identify the exclusion of opposition parties and the generally peripheral nature of Parliament (Jordan and Richardson, 1987: 251-2).

A proper comparison requires us to gauge the modern use of Sweden's distinctive commissions rather than assume that they continue in the same manner described over 25 
years ago. Arter (2008: 162) notes that their number has reduced - from 409 in 1981 to 277 in 1997. Two-fifths of commissions were 'one-person' in 1981, rising to two-thirds by 1997 , reinforcing the idea that formal consultation is on the decrease in Sweden. Bergman and Bolin (2010: 279) note that many business groups now refuse to nominate representatives to commissions - suggesting that the commission arena is not central to policymaking (Arter, 2008: 164).

Recent developments reinforce this impression of change (Kommittéberättelse, 2012). In 2012, 209 commissions of inquiry were formally active (some are dormant). Of these, 66 were launched in 2012, while 74 were concluded and disbanded. Three-quarters (155 of 209) were one-person commissions. Their remits are narrow, often focusing on a specific legal or technical issue. The vast majority of these one-member-commissions had no political affiliation; they were primarily civil servants, senior lawyers, and academics with special expertise. Some had individual investigators with a political background, such as incumbent members of parliament, as well as former party leaders or ministers, but their remits tended to be non-party-political. Commissions of inquiry with parliamentary representation were few; in 2012, fifteen out of the 209 commissions had representation from all the eight parliamentary parties, including the new and often-ostracised Sweden Democrats.

Commissions of inquiry are also given less time to work than before (Petersson, 1994: 90f). Most are given one to two years. Of the 74 that concluded their work in 2012, only seven had been launched more than three years earlier. There are examples of very old commissions, but they tend to be permanent or long-term working groups, with shifting compositions (the oldest had been launched in 1968). One example is the 'Defence Commission', with broad parliamentary representation, which presents regular reports on Sweden's security situation and its implications for defence policy. Since its original launch in 1992, it has presented 14 reports. Its 2013 report will inform a defence review in 2015. Foreign and defence policy are still regarded as areas where broad majorities are preferable. However, this kind of 'consensus-inducing' commission is the exception, not the rule.

Against this background, formal interest group inclusion has become less common. Four out of the 209 commissions in 2012 had broad interest group representation. This does not mean that interest groups are detached from the formal policy making process. Instead they give their views during the consultation 'remiss' stage, after a commission of inquiry has submitted its final report. During this stage, organisations and institutions, such as courts of law, are invited to give their views on the report. It is quite common for governments to take views and information from the remiss stage into account when preparing a parliamentary bill emanating from a commission of inquiry (some proposals have been 'killed' by the remiss process).

These developments reflect a degree of Swedish government ambivalence about the notion of commissions of inquiry as vital instruments of democracy. As Amna (2010: 557f) notes, they were already subject to criticism - as slow, expensive and inefficient - in the early $20^{\text {th }}$ century. They were also subject to regular culls, often by the Social Democrats. So, recent developments could be seen as efforts to rationalise the policy making process. The trends 
towards fewer members, shorter time to work and more narrowly defined remits can be interpreted this way. Whether this has reduced the degree of consensus is open to debate, but we can at least identify an attempt to supplement consensus-building with expertise.

Overall, the formal side to consultation in Sweden is distinctive; it has few direct counterparts in the UK and it is not a practice emulated in a devolved Scotland. However, it is also something that may be of diminishing importance. The nature of commissions of inquiry has evolved into something rather different to the way it is portrayed in earlier scholarly work: long processes of consensus building often give way to short processes of information gathering by experts. Consultation may be taking place in less formal arenas without a requirement for everyone, including political parties, to be consulted routinely - a process that suggests that Swedish practices are, to some extent, converging with those in the UK.

\section{Government, Groups and Consultation: Is Scotland closer to Sweden or the UK?}

Any comparison between Sweden, the UK and Scotland should consider practical alongside cultural factors, in five main ways. First, we can identify striking similarities in consultation practices despite their ostensibly different political systems and cultures. Interviews conducted by X, Author, Y and Z from 1999 to the present day ${ }^{\text {iv }}$ confirm that groups are generally satisfied with consultation processes in Scotland, with many pointing directly to the design of a new devolved consensual political system as a key factor in explanation. However, interviews with equivalent UK groups demonstrate a striking degree of similarity in attitudes. In both arenas, there is a combination of a small number of high profile and controversial issues, in which close group-government arrangements may not be apparent, and a much larger number of issues on which groups and government cooperate routinely (Author, 2008; 2009).

Second, consensual consultation practices in Scotland in the first decade of devolution resemble those of Sweden before economic conditions had an impact. In Scotland, devolution was accompanied by a significant increase in public expenditure and there were comparatively few major policy disagreements. Competition for resources was not fierce because most policy programmes were relatively well funded. Scottish Governments were able to maintain or develop a 'universal' welfare state similar to that of Sweden (see Steinmo, 2010: 35) and often mark significant departures from UK Government policy (Author, 2011a; Author, 2013; Author, 2012). Examples of added universal coverage can be found in 'free personal care' for older people, the abolition of prescription and eye test charges, and the abolition of higher education tuition fees - at a time when many charges in England were increasing (such as tuition fees) or means tested (personal care). The prospect of reduced Scottish Government budgets has prompted some debate in Scotland about the affordability of universal coverage, with harder choices likely to produce more competition between groups (Author, 2013). This experience in the first decade has parallels to the golden age of corporatist consultation in Sweden during early post-war economic growth - a process followed by more problematic relationships when undermined by new socio-economic constraints. 
Third, Scotland is much closer to Sweden in terms of size: Sweden's population is 9.5 million; Scotland's is 5.25 million. Its size and scope allows relatively close personal relationships to develop between key actors. For example, a ministerial or senior civil servant team could meet with all University, local authority or health board leaders in one small meeting room, while Sweden may require a large meeting room, and the UK Government would require a lecture theatre. Further, the policy capacity of the Scottish Government is relatively low, prompting civil servants to rely more - for information, advice and support - on groups outside of government. As Keating (2010: 258) argues, the consequent Scottish policy style resembles that of 'other devolved governments in Europe' and many relatively 'small independent states' which are 'weak compared with [large] nation-states, limited in their powers, resources and policy capacities'. A smaller government with fewer resources is more obliged to consult with other organisations, producing a tendency for reciprocal and often-consensual relationships to develop. This is not absent in the UK but the relative necessity to consult may influence the nature of relationships.

Finally, Scotland increasingly shares with Sweden a greater willingness to devolve policymaking, or relatively high implementation discretion, to bodies such as local authorities. Indeed, the increased role for local authorities, coupled with a tendency for the national government to produce framework legislation, which is broad enough to secure widespread consensus, helps explain Sweden's ability to maintain its consensual image. As Bergman and Bolin (2010: 280) note, local government has taken on responsibility for, 'about 70 percent of total government consumption'. Further, central government has 'shifted from steering by detailed instructions to a system of general policy targets'. Consequently, it has become increasingly difficult to 'deliver on promises about services and public-sector reforms. Today, it is very much up to local governments to actually decide and implement these promises'.

In Scotland, we can detect a similar focus on: (a) a broad national strategy, the National Performance Framework (Scottish Government, 2007); and (b) the growing importance of local government to policymaking, even though there are centralist moves in other areas, such as police, fire and further education (Author, 2013: 142). Scotland often has a 'bottom up' approach to implementation in which flexibility is built into the initial policy; there is less evidence of top-down control, linked to targets which are monitored and enforced energetically, that we associate with the UK government (Author, 2011a: 184; Greer and Jarman, 2008). Implementing bodies are often given considerable discretion and pressure participants are well represented in working groups (Author, 2011a: 130; Author, 2013: 139), producing potentially different group-government dynamics when new networks form at more local levels of government.

Such similarities should be viewed in the context of a devolved Scotland compared with an independent Sweden. For example, the idea of a 'Scottish Policy Style' is often misleading since groups seeking influence in Scottish affairs may be lobbying more than one level or type of government, including the UK and EU, each with the potential for different relationships to emerge. Its group-government arena tends to be limited primarily to spending and regulatory areas (Author, 2013: 242). The Scottish Government does not control the tax 
system and there is no equivalent to the Swedish high-tax-high-spending relationship. Scotland may not devolve more welfare responsibilities to local authorities because it is not responsible for welfare policy. A comparison of levels of corporatism is also less meaningful because the Scottish Government does not have responsibility for most aspects of economic policy that might be negotiated between businesses and unions.

\section{Conclusion}

The devolved Scottish political system contains elements of the UK 'majoritarian' democracy and the Swedish 'consensual' democracy but these labels provide problematic points of comparison. The UK does not live up to its majoritarian image. It shares with other systems a tendency to divide policymaking into subsystems, consult with affected interests, and try to build consensus and consent for public policy. In that sense, the UK, Sweden and Scotland broadly share a policy style. Similarly, we warn against comparing Scotland with a Swedish consensualism that is assumed rather than demonstrated. The Swedish system contains consensual elements and a distinctive role for parliament in the policy process, but we should not exaggerate its distinctiveness with reference to a misleading caricature of UK politics.

Scottish political institutions were designed partly to move away from 'old Westminster' in favour of consensus democracy. A more proportional electoral system would increase the need for parties to cooperate, while a new committee system would give parties a new arena in which to do so. Yet, a Westminster culture and frame of reference is still important. From 1999-2007 a coalition government operated in a majoritarian manner by dominating the legislative process and the plenary and committee arenas. There was minimal evidence of the tendency in Sweden to institutionalise cooperation between governing and opposition parties. This did not change following minority government in Scotland. The creation of new institutions was not accompanied by the type of bargaining culture we associate with Sweden. Nor does the Scottish Parliament engage in the pre-legislative scrutiny that we find in Swedish commissions. Instead, parties seem reluctant to improve Scottish Government legislation before it comes to Parliament. A focus on policymaking suggests that the Scottish Parliament is often a peripheral body and that its opposition parties have few arenas for routine influence.

In the group-government arena, Scotland shares many features with Sweden that are found less in the UK - partly because the former countries are small enough to allow personal relationships to develop between relatively senior policymakers and pressure participants. The early economic settlement allowed Scotland to develop a welfare state much closer to the 'Swedish model' than the UK, which is more likely to means test and charge for services and/ or subject them to greater 'marketisation'. Scotland also shares with Sweden a relative willingness to devolve policymaking responsibility to local government - a decision that may often shift group-government relationships away from the centre. Yet, Scotland also shares with the UK a broad tendency to consult informally, with no real equivalent to the Swedish 'structured consultation'. 
The likelihood of an independent Scotland becoming more like countries such as Sweden is still an open question (Keating, 2009) and a topic of current debate. An independent Scotland, with the power to raise taxes, has the potential to develop Sweden's policy or model of high-tax-high spending. However, a more fundamental shift would be required to move towards policy-making practices, such as bargaining between governing and opposition parties, and maintaining 'corporatist' relationships between government, business and labour, associated with Sweden's romantic image.

\section{References}

Amna, E. (2010) '"Speaking Truth to Power"? Statsvetarna och kommitéväsendet', in Jerneck, M. and Badersten, B., eds., Kontraster och nyanser. Svensk statsvetenskap $i$ brytningstid, pp. 512-567 (Lund: Statsvetenskaplig Tidskrift)

Anton (1969) 'Policy-Making and political Culture in Sweden', Scandinavian Political Studies, 4, 88-102

Arter, D. (1984) The Nordic Parliaments (London: C. Hurst)

Arter, D. (2004) The Scottish Parliament: A Scandinavian-Style Assembly? (London: Frank Cass)

Arter, D. (2006) 'Introduction: Comparing the legislative performance of legislatures', Journal of Legislative Studies, 12, 3, 245-57

Arter, D. (2008) Scandinavian Politics Today 2nd ed. (Manchester: Manchester University Press)

Baumgartner, F. and Jones, B. (2009) Agendas and Instability in American Politics 2nd edn (Chicago: Chicago University Press).

Bergman, T. and Bolin, N. (2011) 'Swedish Democracy: Crumbling Political Parties, a Feeble Riksdag, and Technocratic Power Holders? In (eds) Bergman \& Strom The Madisonian Turn: Political Parties And Parliamentary Democracy In Nordic Europe, pp. 251-293 (Ann Arbor: University of Michigan Press)

Bergman, T. and Strom, K., eds., (2011) The Madisonian Turn: Political Parties And Parliamentary Democracy In Nordic Europe (Ann Arbor: University of Michigan Press)

Christiansen, P. M. and Togeby, L. (2006) 'Power and Democracy in Denmark: Still a Viable Democracy', Scandinavian Political Studies, 29, 1, 1-24

Eckstein, H. (1960) Pressure Group Politics: The Case of the British Medical Association (London: George Allen and Unwin Ltd.)

Einhorn, E. and Logue, J. (2003) Modern Welfare States $2^{\text {nd }}$ ed. (London: Praeger)

Elder, N., Thomas, A. and Arter, D. (1982) The Consensual Democracies? (Oxford: Martin Robertson)

Electoral Reform Society Scotland (2013) Democracy Max (Edinburgh: ERS) http://www.electoral-reform.org.uk/vision (accessed 18.3.14)

Flinders, M. (2010) Democratic Drift (Oxford: Oxford University Press)

Greer, S. and Jarman, H. (2008) 'Devolution and Policy Styles', in A. Trench (ed.) The State of the Nations 2008 (Exeter: Imprint Academic)

Harvey, M. (2014) 'A Scottish Nordic Model?' (Edinburgh: ESRC Future of the UK and Scotland) http://www.futureukandscotland.ac.uk/blog/scottish-nordic-model (accessed 18.3.14)

Heclo, H. (1978) 'Issue Networks and the Executive Establishment', in A. King (ed.) The New American Political System (Washington, DC: American Enterprise Institute) Heclo, H. and Madsen, H. (1987) Politics in Sweden (Philadelphia: Templeton University Press) 
Heisler, M. and Kvavik, R. (1974) 'The European Polity Model', in M. Heisler (ed.) Politics in Europe (NY: David McKay).

Hilson, M. (2008) The Nordic Model : Scandinavia Since 1945 (London: Reaktion Books) Hinnfors, J. (1997) 'Still the Politics of Compromise? Agenda Setting Strategy in Sweden', Scandinavian Political Studies, 20, 2, 159-77

Jimmy Reid Foundation (2013) The Common Weal: a model for economic and social development in Scotland' (Glasgow: Jimmy Reid Foundation) http://reidfoundation.org/wpcontent/uploads/2013/05/The-Common-Weal.pdf (accessed 18.3.14)

Jordan, G. (1981) 'Iron Triangles, Woolly Corporatism and Elastic Nets: Images of the Policy Process', Journal of Public Policy 1, 1: 95-123

Jordan, G. and Maloney, W. (1997) 'Accounting for Subgovernments: Explaining the Persistence of Policy Communities', Administration and Society, vol.29, 5, 557-583

Jordan, A. G., \& Richardson, J. J. (1983) 'Policy communities: the British and European policy style’ Policy Studies Journal, 11, 4, 603-615.

Jordan, A.G. and Richardson, J.J. (1987) Government and Pressure Groups in Britain (Oxford: Clarendon Press)

Jordan, G., Halpin, D. and Maloney, W. (2004) 'Defining Interests: Disambiguation and the Need for New Distinctions?' British Journal of Politics and International Relations, 6, 2: 195-212.

Keating, M. (2010) The Government of Scotland (Edinburgh: Edinburgh University Press)

Keating, M. (2009) The Independence of Scotland (Oxford: Oxford University Press)

Kommittéberättelse 2012. Regeringens skrivelse 2012/13:103

Keating, M. and Harvey, M. (2014) 'The Political Economy of Small European States: And Lessons for Scotland' National Institute Economic Review, 227, 1, R54-R66.

Kerr, P. and Kettell, S. (2006) In defence of British politics: The past, present and future of the discipline', British Politics 1, 1, 3-25

Kvist, J. and Greve, B. (2011) 'Has the Nordic welfare model been transformed?' Social Policy \& Administration, 45, 2, 146-160.

Lijphart, A. (1984) Democracies (New Haven: Yale University Press)

Lijphart, A. (1999) Patterns of Democracy (New Haven, Conn: Yale University Press)

Lipset, S.M. and S. Rokkan (eds) (1967) Party Systems and Voter Alignments: Cross National Perspectives (London: Collier-MacMillan).

Marsh, D. (2008) 'Understanding British government: Analysing competing models', British Journal of Politics and International Relations 10, 2, 251-69

Mattson, I. and Strøm, K. (2004) 'Committee Effects on Legislation', in H. Döring,

and M. Hallerberg (eds), Patterns of Parliamentary Behaviour (Aldershot:

Ashgate)

Milne, R. (2014) 'Scottish nationalists look to Nordic model for independence', ft.com, $2^{\text {nd }}$ February $\quad$ http://www.ft.com/cms/s/0/57664dc2-8bf8-11e3-bcf200144feab7de.html\#axzz2wJhqQdL1 (accessed 18.3.14)

Mitchell, J. (2008) 'Minority governments, constitutional change and institutional cultures in Scotland' in A. Brazier and S. Kalitowski (eds.) No Overall Control? (London: Hansard Society)

Østerud, Ø. and Selle, P. (2006) 'Power and Democracy in Norway: The Transformation of Norwegian Politics' Scandinavian Political Studies, 29: 25-46

Procedures Committee (2003) The Founding Principles Of The Scottish Parliament http://www.scottish.parliament.uk/business/committees/historic/procedures/ reports-03/prr03-03-vol01-04.htm

Rhodes, R. (2011) Everyday Life in British Government (Oxford: Oxford University Press) Richardson, J. and Jordan, G. (1979) Governing Under Pressure: The Policy 
Process In A Post-Parliamentary Democracy (Oxford: Robertson)

Richardson, J. and Jordan, G. (1983) Overcrowded Policymaking: Some European

Reflections, Policy Sciences, 15, 247-68

Richardson, J., Gustafsson, G. And Jordan, G. (1982) 'The Concept of Policy Style' in

Richardson, J. (ed.) (1982) Policy Styles in Western Europe (London: Allen \& Unwin)

Richardson, J. (ed.) (1982) Policy Styles in Western Europe (London: Allen \& Unwin)

Ruin, O. (1982) 'Sweden in the 1970s: Policymaking Becomes More Difficult' in

Richardson, J. J. (ed.) (1982) Policy Styles in Western Europe (London: Allen \&

Unwin)

Rydgren, J. (2006) From Tax Populism to Ethnic Nationalism. Radical Right-Wing Populism in Sweden (New York: Berghahn).

Sandberg, L. and Demker, M (2013) 'Ökat motstånd mot flyktingar men starkt stöd för skäl till uppehållstillstånd', in Weibull, L., Oscarsson, Hh and Bergström, A, eds., Vägskäl (Göteborg University: The SOM institute).

Scottish Constitutional Convention (1989) Towards Scotland's Parliament (Edinburgh)

Scottish Constitutional Convention (1995) Scotland's Parliament, Scotland's Right http://www.almac.co.uk/business_park/scc/

Scottish Government (2007) Performance (Edinburgh: Scottish Government)

http://www.scotland.gov.uk/About/Performance

Scottish Office (1998) Shaping Scotland's Parliament (Edinburgh: Scottish Office).

Simon, H. (1976) Administrative Behavior 3rd ed. (London: Macmillan)

Steinmo, S. (2010) The Evolution of Modern States (Cambridge: Cambridge University Press)

Widfeldt, A. (2000) 'Scandinavia; Mixed success for the Populist Right', Parliamentary Affairs, 53, 3, 486-500.

\footnotetext{
${ }^{\mathrm{i}}$ Albeit not in a consistent way and, unlike in 1997, not by a large collection of groups at the centre of the independence debate. Perhaps the strongest exponent of Nordic practices is the Jimmy Reid Foundation (2013) which uses a discussion of the 'Nordic Social and Economic Model', to recommend reducing economic inequality, maintaining a strong welfare state, supporting corporatism, and furthering local democracy (to further 'equality, high trust in government and social cohesion' - Milne, 2014). Nordic Horizons (http://www.nordichorizons.org/) focuses more on events to improve Scottish knowledge of Nordic countries. Scotland's First Minister (2007-present) Alex Salmond used the phrase 'Arc of Prosperity' in a speech in 2008. $\mathrm{He}$ argued that small states were flexible and able to adapt quickly to economic circumstances. He mentioned Sweden briefly, but the greater focus was on countries such as Iceland. The Scottish National Party has since focused more on Norway as an example of a country with a sovereign oil fund (Author, 2013; Milne, 2014). The strongest current rejection of a Westminster political style is articulated by the Electoral Reform Society Scotland (2013).

ii This shift in group-government relations was a development common to many political systems, including the US and UK, from that period (Heclo, 1978: 94; Jordan, 1981: 96-00; Author, 2012: 42).

iii A problem complicated by the multi-level party system,. The Labour, Liberal Democrat and Conservative parties maintain separate policy positions in Westminster.

iv Approximately 400 interviews in the UK since devolution, including approximately 200 interviews in Scotland - see Author (2013).
} 